\title{
ANALYSIS OF SOCIAL NORM IN PERSONAL TAXPAYERS' COMPLIANCE
}

\author{
Susanto Beny Nurwig*, Syah Tantri Yanuar Rahmat \\ Master of Management Program, University of Esa Unggul, Indonesia \\ *E-mail: benny.susanto546@gmail.com
}

\begin{abstract}
Present research aims to prove: the effect of social norm on compliance; the effect of the taxpayers' awareness on compliance; the effect of social norm on private norm; the effect of private norm on tax compliance; the effect of private norm on the tax justice system; the effect of the perception of the tax justice system on government trusts; the effect of government trust on compliance; the dominant variable affecting taxpayers compliance registered in South Jakarta. In this research, to analyze and to know the significant level and interrelationship between variables, analysis method of Structural Equation Model (SEM) is used. With this method it can be seen the effects and the relationships between exogenous and endogenous variables associated to researched problems. In this study 280 respondents were obtained by visiting taxpayers, taxpayer consultation to tax office and through socialization as well as tax counseling, with data used in the analysis of 250 respondents with dissemination covering gender, age, status, education level, and income. From the result of $\mathrm{H} 1-\mathrm{H} 6$ research, there is no effect because the result of analyst does not support hypothesis. However, $\mathrm{H} 7$ shows the results of the analysis support the hypothesis that the perception of justice can be especially important in tax compliance.
\end{abstract}

\section{KEY WORDS}

Social norm, taxpayer compliance, private norm, justice.

Tax is one of the sources of state revenue that gives the most significant role in the State Budget (APBN). The increasingly decisive role of taxation in state administration needs the active participation of taxpayers, stakeholders, and all Indonesians. So far, the tax target set in the State Budget always uses macro assumptions. Macroeconomic indicators such as the rate of economic growth and inflation play an important role in generating tax targeting formula. Supposedly, the tax target is calculated from a micro approach such as the number of registered taxpayers, the number of taxpayers, and taxpayer compliance. This formula will result in a routine tax base. Furthermore, added potential taxes will be the basis of additional new taxes, such as the potential sector and disbursement of tax receivables.

The combination between the previous year's routine tax base and the potential tax will be a more appropriate tax target in 2017 by not raising tax targets as in previous years. The assumption is that the state budget posture should be credible and begun with setting targets close to the actual conditions, when the tax base is fixed in 2017, then the next year the tax will move more aggressively and measurably. In State Budget use, the government closes the year of 2016 with a relatively safe budget deficit condition, the achievement of tax realization itself also affects the condition.

To achieve the tax target, continuous awareness and compliance of the taxpayer community must be grown in order to meet the tax obligation in accordance with the prevailing regulations. Considering taxpayers' awareness and compliance are important factors for increasing tax revenues, it is necessary to intensively examine the factors affecting taxpayer compliance, particularly personal taxpayer compliance.

The research done by Cialdini and Trost (1988) finds that social norm as rules and standards understood by group members and guide or limit social behavior without being compelled by law. The four categories of effects are included in this definition: general society behavior (the injunctive norm), the expectations of others who are valued for their own behavior (subjective norm), self-expectation for appropriate behavior or ethical beliefs (private norm), standards evolving from observation the behavior of others (descriptive 
norm). Therefore, the definition of social norm includes not only external social influences, but also personal (or ethical) moral beliefs in individuals. Cialdini and Trost (1998) states that in general social norm have an effect on taxpayer tax compliance behavior. Private norm and subjective norm have a direct effect on taxpayer tax compliance, while injunctive norm and descriptive norm have an indirect effect on taxpayer compliance.

The conclusion is that social norm has an effect on taxpayer tax compliance. In addition to social norm, other factors that may affect the taxpayers in fulfilling their tax obligations or tax compliance is the awareness of the taxpayers, given the awareness and compliance of taxpayers is an important factor for increasing tax revenues, it is necessary to be intensively reviewed about the factors that affect the compliance of taxpayers, especially personal taxpayers.

These studies examine further from the initial research conducted in the study of the science of financial behavior. Cowell (1990), Porcano and Price (1993), Alm et al. (1999), Davis et al. (2003) on behavior in tax compliance. Furthermore, these studies examine the effect of compliance and social factors by Bobek and Hatfield (2003) and Torgler (2007). To enrich a deeper literature review of the effects regarding to social norm, it also shows that private norm is important because affecting ethical beliefs directly means that affecting compliance behavior. This research undertakes the development of research conducted by (Wenzel, 2004; and Bobek et al., 2007).

Based on the above research problems, this study is conducted to prove: 1) the effect of social norm on compliance; 2) the effect of the taxpayers' awareness on compliance; 3) the effect of social norm on private norm; 4) the effect of private norm on tax compliance; 5) the effect of private norm on the tax justice system; 6 ) the effect of the perception of the tax justice system on government trust; 7 ) the effect of government trust on compliance; as well as to prove the dominant variable affecting taxpayer compliance registered in South Jakarta.

Social Norm and Taxpayer Compliance. Social norm can encourage compliance towards the Tax Law by helping individuals to obey the rules, therefore if the individual feels that the other taxpayer does not have an intention to comply with taxes, then the individual does not have moral and tends to avoid taxes (Torgler, 2003). Descriptive norm explicates the behavior of others in providing information about successful behaviors for others (Cialdini and Trost, 1998), therefore descriptive norm helps individuals determine the success of compliance because descriptive norm provides valuable information to individuals to guide behavior. The compliance of social norm is the result of the individuals' willingness to obey the group (Deutsch and Gerard, 1955; Cialdini et al., 1991; Nail et al., 2000). The injunctive norm explains what is socially acceptable in groups and individuals will obey the norms in the search for social agreements. Injunctive norm should affect behavior in situations that include tax compliance. The research conducted by Bobek et al. (2007) examines the effect of norm of having tax compliance behavior and finding that injunctive norm helps predict compliance.

The logic of the above thinking is in line with the research done by Bobek et al. (2007) which resulted in the conclusion that the variable of social norm can be used as an indicator for tax compliance. Therefore, our hypothesis is as follows:

$\mathrm{H}_{1}$ : Social norm will increase taxpayer compliance.

Taxpayer Awareness and Taxpayer Compliance. Lerche (1980) argues that taxation awareness frequently becomes a constraint in the problem of collecting taxes from the public. The above-mentioned logic conforms to Sanders' (2008) and Palil et al. (2013) which resulted in a conclusion that the higher the awareness of taxpayers, the higher the level of taxpayer compliance. Hence, our hypothesis is as follows:

$\mathrm{H}_{2}$ : Taxpayer awareness will increase taxpayer compliance.

Social Norm and Private Norm. Social norm has an indirect effect on compliance through the internalization of private norm, in addition to the direct effects of descriptive social norm on tax compliance decisions, descriptive norm is also shared by individuals and affect personal morals. Wenzel (2005) suggests that support for private norm as a mediator of relationships of social norm, but private norm is only a partial mediator in this relation. According to Bobek et al. (2007), subjective social norm is the norm that is mostly experienced by individuals. The actual situation can be difficult to distinguish between private 
norm and subjective norm; therefore, subjective norm will also have a direct effect on tax compliance decisions through mediation of private norm. The above-mentioned logic is in accordance with the finding of Bobek et al. (2013) which gives a conclusion that the social norm variable can be used as an indicator for the personal norm. Therefore, our hypothesis is as follows:

$\mathrm{H}_{3}$ : Social norm will improve private norm.

Private Norm and Taxpayer Compliance. Internalizing social values in shaping the personal standards of behavior that can be accepted by the values of closest individuals. Individuals surrounded by family members and friends who support taxpayer compliance are also more likely to demonstrate ethical beliefs in the support of behavior. The abovementioned logic is in line with the finding generated by Bobek et al. (2007) conducting research on 254 students and employees in Australia, Singapore and the United States. The results show that private norm is stronger than social norm. Thus, our hypothesis is as follows:

$\mathrm{H}_{4}$ : Private norm will increase taxpayer compliance.

Private Norm and Government Trust. Taxpayers trust the government, so taxpayers are more willing to pay taxes (Torgler, 2003; Torgler et al., 2008). The studies conducted in various countries including European countries (Belgium, Poland, Spain, and Switzerland), transition countries (Russia, Estonia, Latvia, Lithuania, Belarus, and Bulgaria) and Asian countries (for example, India), Torgler (2003) believes that trust in government has a positive relationship with the spirit of taxation. Therefore, our hypothesis is as follows:

$\mathrm{H}_{5}$ : Personal tax compliance norm will increase government trust.

Government Trust and Justice Perception. Governance is considered good if it has a fair tax system. The government provides a political system that is not corrupt (Cummings et al., 2009). Willingness to pay taxes can be increased if the government has fair treatment for all taxpayers (Leonardo, 2011) and that extending trust to the government will encourage the government to be fair (Leonardo, 2011). The trust theory as a heuristic provides insight into trust and helps to explain individual to support for government action. Justice is specifically shown to be the strongest estimate of individuals who believe in an organization (Charash and Spector, 2001 and Hubbell and Assad, 2005). This theory suggests that the perception of justice will have a significant effect on individuals' trust. Deconinck (2010) suggests that the information about the equity of an entity or an individual may provide information about the trust of that party. Thus, our hypothesis is as follows:

$\mathrm{H}_{6}$ : Government trust will improve the perception of tax justice system.

Justice Perception and Taxpayers Compliance. Justice refers to the allocation of resources consisting of horizontal equity, vertical equity, and foreign equity (Wenzel, 2002). Horizontal equity means that taxpayers in the same situation have the same tax obligations, while vertical equity means that taxpayers in different financial situations have different tax obligations with different finances. On the other hand, foreign equity refers to the taxpayers receiving from the paid tax. The above-mentioned logic is in line with Richardson's (2008) finding which states a conclusion that the positive relationship between perception of justice and compliance. Therefore, our hypothesis is as follows:

$\mathrm{H}_{7}$ : Justice Perception will increase taxpayer compliance.

\section{METHODS OF RESEARCH}

This research is categorized as an explanatory research that will prove the causal relationship between two or more variables. In this present study, to determine the effect of social norm and awareness of taxpayers on tax compliance with the mediation of private norm, perception of justice, and trust of the government. This research is a quantitative research and the data obtained from this research is primary data obtained directly from the research respondents.

The research model that has been developed is expected to explain the cause and effect relationship between variables and then is able to create a useful managerial implication in accordance with the research variables. In this research, to analyze and to 
know the significant level and interrelationship between variables, analysis method of Structural Equation Model (SEM) is used. With this method, it can be seen the effect and the relationship between exogenous variables and endogenous variables associated with the researched problems.

The data processing technique of Structural Equation Modeling (SEM) with confirmatory factor analysis (CFA) method is used in this research. Observed variables (indicators) illustrate a particular latent variable (latent dimension). As a testing method that combines analysis factors, path analysis and regression, SEM is more a confirmatory than an explanatory method, aiming at evaluating proposed dimensionally and related to this prior study. With this understanding, SEM can be used as a tool to confirm pre-knowledge that has been previously obtained. The approach taken to estimate the SEM model parameters is divided into two: the first is the structural model, it is also called the latent variable relationship. The approach taken to estimate the parameters of the second SEM model is the CFA Analysis (confirmatory factor analysis) as a measurement model consisting of two types of measurement i.e. the measurement model for the exogenous variable and the measurement model for the endogenous variable (independent variable).

Research Respondents. The results of the study involving 280 respondents obtained by way of taxpayer visits, taxpayer consultation to the tax office, and through socialization as well as tax counseling, with data used in the analysis of 254 respondents with dissemination covering gender, age, status, education level, and income. The questionnaire distributed to 280 respondents, 254 questionnaires or $90,71 \%, 30$ questionnaires or $10,71 \%$ do not return. The questionnaires do not return because the respondents do not want to fill out the questionnaires, while from the total questionnaire data returned only 250 questionnaire or $89,29 \%$ that can be processed, while 4 questionnaires or $1,43 \%$ cannot be processed because the questionnaires are not filled in completely.

\section{RESULTS OF STUDY}

The measurement models the relationship between latent variables and observed variables. The relationship is reflective where the observed variables are reflections of related latent variables. Determination of observed variables reflects latent variables. Based on the substance of the study concerned, the measurement model seeks to confirm whether the observed variables are indeed a reflection of latent variables. The independent variables in this research are social norm and taxpayers' awareness. While the dependent variable is taxpayers' compliance mediated by private norm variable, government trust, and perception of justice. It is referring to Structural Equation Modeling (SEM) method where respondent data is analyzed using analysis software.

Testing 1: Chi Square

Chi Square value: 154,90 . The smaller the model, the more appropriate between model theory and sample data (chi square value divided by degree of freedom). Ideal value of $<3$ is good fit. In addition, divider result obtained value of 1,395 . This indicates an adequate match since the smaller value of $<3$ is good fit.

Testing 2: Root Mean Square Error of Approximation (RMSEA)

RMSEA $=0,041$, then the match is sufficient good fit. (Where RMSEA of $<0,05$ is close fit, RMSEA of $<0,08$ is good fit, 0,08 $<$ RMSEA $<0,10$ marginal fit, and RMSEA $>0,10$ poor fit). Confidence intervals are used to assess the achievements of RMSEA estimates. At the output, it is shown $90 \%$ of confidence interval (between 0,$025 ; 0,055$ ) is in about of the RMSEA. P-value for test of close fit (RMSEA < 0,05$)$ for this study is 0,84 .

Testing 3: Expected Cross Validation Index (ECVI)

ECVI model $(0,97)$ is compared to ECVI saturated model $(1,23)$ and ECVI independence model $(6,58)$. ECVI model is slightly smaller than ECVI saturated model and the difference is much greater than ECVI independence model, or in other words, ECVI saturated closes more to ECVI model than ECVI independence model, and $90 \%$ of confidence interval is 0,$85 ; 1,12$, then a good match is obtained (around the ECVI model). 
Testing 4: Akaike Information Criterion (AIC) and Consistent Akaike Information Creterion (CAIC)

AIC model $(242,12)$ is compared to AIC saturated model $(306,00)$ and AIC independence model $(1639,19)$. AIC model is slightly smaller than AIC saturated model and the difference is much larger than AIC independence model, hence it shows a good match. The CAIC model $(432,03)$ is far from CAIC saturated model $(997,78)$ and furthermore CAIC independence $(1716,05)$ indicates a good match.

Testing 5: Fit Index

Normed fit index $(\mathrm{NFI})=0,90$ shows good fit. CFI 0,97 (above 0,90) indicates good fit. Tucker Lewis Index or Non Normed Fit Index (NNFI) = 0,96 (above 0,90) indicates good fit. Incremental Fit Index (IFI) = 0,97 (above 0,90) indicates good fit. Relative Fit Index (RFI) = 0,88 (below 0,90) shows marginal fit. Parsimonius Normed Fit Index (PNFI) = 0,74 (above $0,6)$ used for model comparison shows good fit.

Testing 6: Critical $N$

Critical $N(C N)=239,83>200$ models representing sample data or good fit.

Testing 7: Goodness of Fit

Root mean Square Residual (RMR) is the residual average value generated from the fitting between the Variance-co Variance matrix of the model with the Variance-co Variance matrix of the data sample. Standardized RMR $=00,5$ (indicates good fit. Goodness of Fit Index $(\mathrm{GFI})=0,93$ (above 0,90) shows good fit and Adjusted Goodness of Fit Index (AGFI) = 0,90 indicates good fit. Parsimony Goodness of Fit Index (PGFI) $=0,68$ can be used in the model comparison indicating an adequate match.

From the analysis in group one to group seven, some tests show adequate matches such as Chi Square, ECVI, AIC CAIC, and Fit Index. There are results of close-fit results for RMSEA. There are results of marginal fit results for RFI. From the above results, it can be concluded the fit of the model (goodness of fit) of this model is eligible. Furthermore, this research produces a path diagram such as the following figure path:

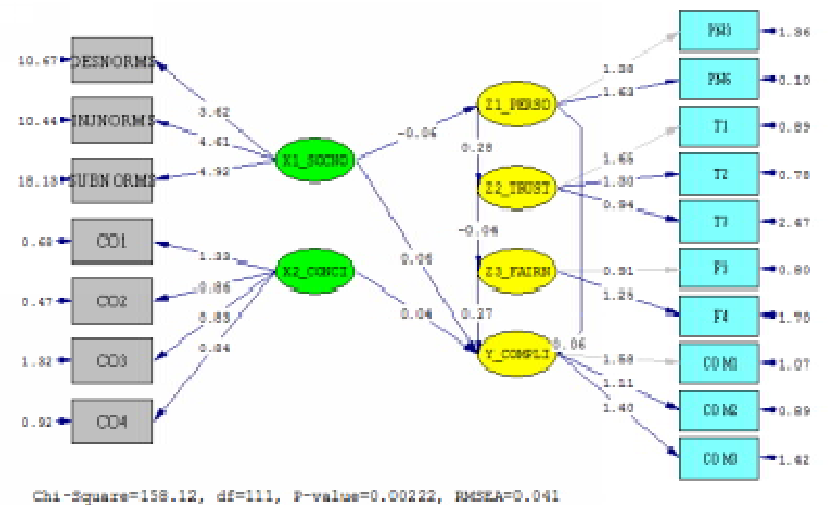

Figure 1 - Model of Structural Equation -Estimation

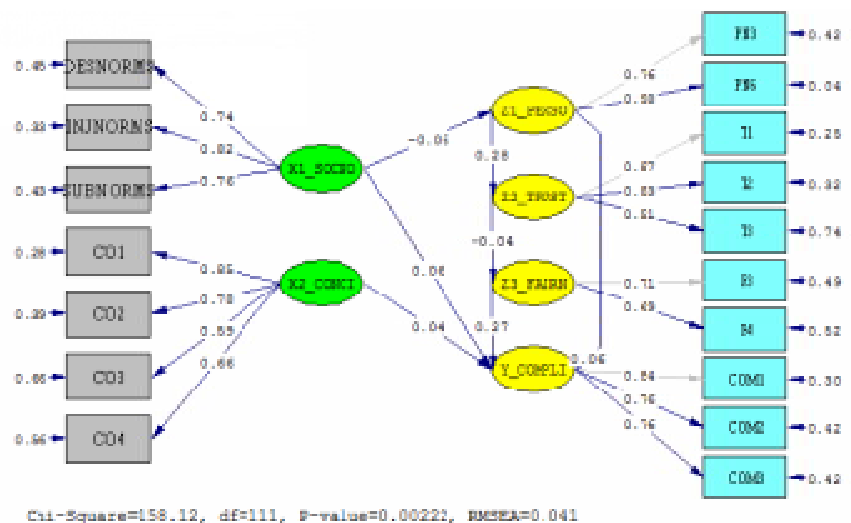

Figure 2 - Model of Structural Equation - Standardized Solution 


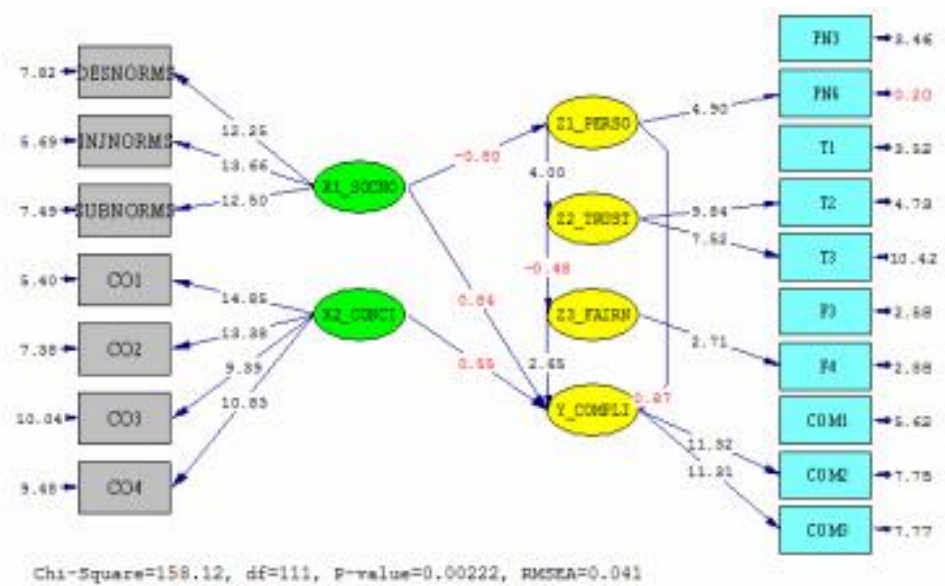

Figure 2 - Model of Structural Equation -t Value

Analysis of Causal Relationships. The theoretical model that has been built in the previous step will be described in a path diagram. Path diagram will make it easier for researchers to see the causality relationships that will be tested. In SEM modeling, the researchers work with concepts that have sufficient theoretical foundations to explain the various forms of relationships. The purpose of using causal relationships analysis is to know the causal relationship of each variable. It can be seen as follows:

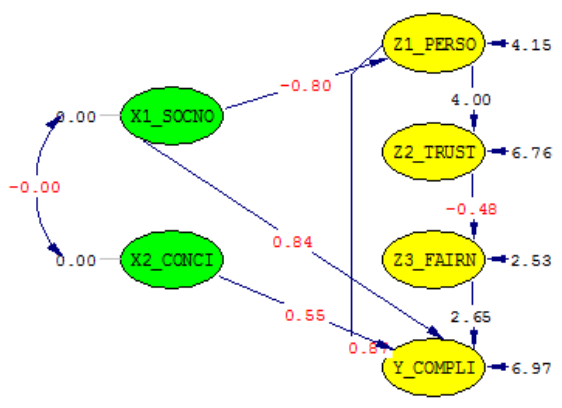

Chi-Square $=158.12, \mathrm{df}=111, \mathrm{P}-\mathrm{value}=0.00222, \mathrm{RMSEA}=0.041$

Figure 4 - Path Causal Relation - $t$ Value

The calculation results of structural equations and reduced form equations, the output of software that is automatically generated on the output program can be seen as follows:

Structural Equations:

Z1_PERSO $=-0.058^{*} X 1 \_S O C N O$, Errorvar $.=1.00, R^{2}=0.0033$

$\bar{Z} 2$ TRUST $=0.28^{\star} \mathrm{Z} 1$ PERSO, Errorvar $=0.92, \mathrm{R}^{2}=0.079$

Z3 FAIRN $=-0.041^{*} \mathrm{Z} 2$ TRUST, Errorvar $=1.00, \mathrm{R}^{2}=0.0017$

Y_COMPLI $=0.060^{\star} Z 1$ ZPERSO $+0.27^{\star} Z 3$ ZFAIRN $+0.063^{*} \mathrm{X} 1$ SOCNO $+0.041^{*} \mathrm{X} 2$ CONCI ,

Errorvar. $=0.92, R^{2}=0.079$

Reduced Form Equations:

Z1 PERSO $=-0.058^{*} X 1$ SOCNO $+0.0^{*} X 2$ CONCI, Errorvar. $=1.00, \mathrm{R}^{2}=0.0033$

Z2_TRUST $=-0.016^{*} \times 1$ SOCNO $+0.0^{*} X 2$ CONCl, Errorvar. $=1.00, R^{2}=0.00026$

Z3 FAIRN $=0.00066 * \bar{X} 1$ SOCNO $+0.0 * \bar{X} 2$ CONCl, Errorvar $=1.00, R^{2}=0.00$

$\mathrm{Y} \_\mathrm{COMPLI}=0.059^{*} \mathrm{X} 1 \_\mathrm{SOCNO}+0.041^{*} \mathrm{X} 2 \_\mathrm{CONCI}$, Errorvar. $=0.99, \mathrm{R}^{2}=0.0052$ 
The estimation of the causal relationship of the above research model can analyze causal relationships. The value of $\mathrm{t}$ value and coefficient of structural equation are summarized in the following table:

Table 1 - T-Value and Coefficient of Structural Equations

\begin{tabular}{|c|c|c|c|}
\hline No. & Path & $T$ Value $(\mathrm{t} \geq 1,96)$ & Con clus i o \\
\hline 1 & SOCNO $\rightarrow$ COMPLI & 0,84 & Not significant \\
\hline 2 & CONCI $\rightarrow$ COMPLI & 0,55 & Not significant \\
\hline 3 & SOCNO $\rightarrow$ PERSO & $-0,80$ & Not significant \\
\hline 4 & PERSO $\rightarrow$ COMPLI & 0,87 & Significant \\
\hline 5 & PERSO $\rightarrow$ TRUST & 4,00 & Not significant \\
\hline 6. & TRUST $\rightarrow$ FAIRN & $-0,48$ & Significant \\
\hline 7. & FAIRN $\rightarrow$ COMPLI & 2,65 & \\
\hline
\end{tabular}

Source: The results of the research process

Based on the above table, it can be identified that the coefficient PERSO $\rightarrow$ TRUST and FAIRN $\rightarrow$ COMPLI has an absolute value $t \geq 1,96$ which means significant, whereas the coefficient SOCNO $\rightarrow$ COMPLI has a value of 0,84 ; coefficient of $\mathrm{CONCI} \rightarrow$ COMPLI has a value of 0,55 ; SOCNO $\rightarrow$ PERSO has a value of $-0,80$; PERSO $\rightarrow$ COMPLI has a value of 0,87 ; TRUST $\rightarrow$ FAIRN has a value of $-0,48$ which is below the standard value $(\leq 1,96)$ meaning not significant.

Hypothesis Testing Results. In this research, there are 7 hypotheses. Hypothesis testing is done with significance level of $5 \%$, so that it obtains critical value $t$ of \pm 1.96 . The hypothesis is accepted if the t-value obtained is $\geq 1.96$, whereas the hypothesis is not supported if the t-value obtained is $\leq 1.96$. Here is the summary of hypothesis test to see if the proposed model is supported by the data:

Table 2 - Hypothesis Testing Results

\begin{tabular}{|c|c|c|c|}
\hline Hypothesis & Hypothesis Statement & $\begin{array}{c}\text { T-Value } \\
\text { value }\end{array}$ & Note \\
\hline H1 & Social norm will increase taxpayer compliance. & 0,84 & $\begin{array}{c}\text { The data do not support the } \\
\text { hypothesis }\end{array}$ \\
\hline H2 & Taxpayer awareness will increase taxpayer \\
compliance & Social norm will improve private norm & $-0,80$ & $\begin{array}{c}\text { The data do not support the } \\
\text { hypothesis }\end{array}$ \\
\hline H3 & Private norm will increase taxpayer compliance. & 0,87 & $\begin{array}{c}\text { The data do not support the } \\
\text { hypothesis }\end{array}$ \\
\hline H4 & Personal tax compliance norm will increase \\
government trust. & 4,00 & $\begin{array}{c}\text { The data support the } \\
\text { hypothesis }\end{array}$ \\
\hline H5 & Government trust will improve the perception of the \\
tax justice system. & $-0,48$ & $\begin{array}{c}\text { The data do not support the } \\
\text { hypothesis }\end{array}$ \\
\hline H6 & Justice perception will increase taxpayer compliance & 2,65 & $\begin{array}{c}\text { The data support the } \\
\text { hypothesis }\end{array}$ \\
\hline
\end{tabular}

\section{DISCUSSION OF RESULTS}

There is no Effect between Social Norm and Taxpayer Compliance. The results of the above analysis test found that: the analysis does not support the $\mathrm{H} 1$ hypothesis. It suggests that the social norm required by the taxpayer to achieve an overall high compliance do not have clear purpose and the spirit of objectivity achievement. It does not encourage and underpin a taxpayer in measuring the level of compliance. This finding is different from previous research conducted by Jimenez and lyer (2016) finding that social norm affects taxpayer compliance.

A deeper discussion to know the root cause of this finding can be seen in the dimensions and indicators of the social norm variables. This present study measures social norm by using dimensions proposed by Jimenez and lyer (2016) in which social norm in this 
study is the cause of behavior because it is affected by the needs that exist in human beings. Dimensions including subjective norm, injunctive norm, and descriptive norm are the needs to achieve compliance measured based on taxpayer behavior tested in this study.

These needs are closely related to the behavior of the taxpayers' effort to achieve taxation obligations. From this dimension, besides, several indicators are built which include the number of taxpayers, the number of taxable income, obeying tax rules, family influence, and the effect of peers from research respondents. The results reveal that the subjective norm dimension does not have an effect on compliance on the object of research.

The results of the tests can make a statement that subjective norm in social norm cannot necessarily affect taxpayers' compliance with tax obligations. It means that there is no significant effect between subjective norms on the intention to implement compliance because subjective norm, such as peers, does not have any effect to predict taxpayer behavior. Peers do not play a role to motivate other peers to be professional and in implementing tax obligations, it should be realized in accordance with the prevailing provisions and regulations.

The second dimension that will be examined as a discussion of the research results in social norm variables is the descriptive norm in which the dimension is intended to help the individual determine the success of compliance and avoidance. It is because descriptive norm provides valuable information to individuals to guide behavior. From the dimension, several indicators are built that include the number of taxpayers avoiding taxes and taxable income.

The results of the test provide a statement that the descriptive norm in social norm cannot necessarily affect taxpayers' compliance in fulfilling their tax obligations. This result is also affected by individuals who feel that other taxpayers have a low intention to comply with taxes. Therefore, they have lower moral and will be more likely to avoid taxes. In the findings of this study, it is found that one of the things that become factors that make social norm does not affect compliance on the object of research is that there is no general descriptive norm on the object of research.

The dimension tested further in the social norm variable is the injunctive norm in which the substance of this dimension is to measure individuals who look for social consent to obey the norms. From this dimension, several indicators are built which include testing to comply with tax and business rules to avoid taxes. From the test results, a statement is revealed that the norm in the social norm cannot necessarily affect taxpayers' compliance in fulfilling their tax obligations. This result is also affected by the injunctive norm indicating the level where an individual feel that the public believes it is important to comply with the law tax. Moreover, the findings of this study, it is found that one of the things becoming the factors that make social norm does not affect compliance to the object of research is the fact that there is no general injunctive norm on the object of research.

Finally, it can make conclusions and explanations of the results of research explicating why the findings of research results reveal there is no effect between social norm and taxpayers' compliance on the object of research. From the research problems described above, the weakness of subjective norm, descriptive norm, and injunctive norm become the factors that cause social norm not have effect on taxpayers' compliance on the object of research.

There is no Effect between Taxpayers' Awareness and Taxpayers' Compliance. The results of the analysis test above found that: the analysis does not support the hypothesis of $\mathrm{H} 2$. It shows that the taxpayer's awareness needed by the taxpayer to achieve an overall high compliance does not have clear purpose and the spirit of objectivity achievement. Moreover, it does not encourage and underpin a taxpayer in measuring the level of compliance. This finding differs from previous research conducted by Sanders (2008) and Palil et al. (2013) which resulted in a conclusion that the higher the awareness of taxpayers, the higher the level of taxpayer compliance.

A more in-depth discussion to see the root of the problem in this finding can be seen in the indicator of the taxpayer awareness variable. This study measures the awareness of taxpayers by using indicators designed by Palil et al. (2013) where taxpayer awareness in 
this study is a tax awareness which frequently becomes a constraint or a problem to collect taxes from the public. On the other hand, there are several indicators that include testing people's dues for development, government duties run smoothly, and sustainable development of research respondents. The results reveals that the indicators do not have any effect on compliance on the research object.

From the test results, it can be made a statement that the indicator in the taxpayers' awareness does not necessarily affect taxpayers' compliance with tax obligations. It means that there is no significant effect between the contribution of the people for the development, the governments' duties run smoothly, and sustainable development for realizing compliance because of the awareness of the taxpayer, the human awareness in understanding reality and how to react or respond to reality. The human awareness includes self-awareness, the past, and the possibility of the future.

Holistically, it can be made conclusions and explanations of the results of research regarding to why the findings of research results revealing there is no effect between taxpayers' awareness and taxpayers' compliance on the object of research. From the research problems above, the weak contribution for the development of the people, the task of the government runs smoothly and sustainable development become the factors that lead awareness of taxpayers to not have effect on taxpayers' compliance on the object of research.

There is no Effect between Social Norm and Private Norm. The results of the above analysis test reveal that: the analysis does not support the $\mathrm{H} 3$ hypothesis. It shows that the social norm required by the taxpayer to achieve an overall high compliance do not have clear purpose and the spirit of objectivity achievement. It does not motivate and underpin a taxpayer in measuring private norm. This finding is different from previous research conducted by Jimenez and lyer (2016) concluding that social norm affects private norm.

A deeper discussion that looks for the root cause of this finding can be seen in the dimensions and indicators of the social norm variable. This study measures social norm by utilizing dimensions of Jimenez and lyer (2016) in which social norm in this study is the cause of behavior because it is affected by the needs that exist in human beings. The aforementioned dimensions including subjective norm, injunctive norm, and descriptive norm are the needs to achieve compliance measured based on taxpayers' behavior tested in this study.

These needs are closely related to the behavior of the taxpayers' effort to achieve taxation obligations. From this dimension, several indicators are built which include testing the number of taxpayers, the total of taxable income, obeying the tax rules, the effect of the family, and also measuring the effect of peers of the research respondents. The results clearly reveal that the subjective norm dimension does not give effect to the personal norm on the research object.

The results of the test make a statement that subjective norm in social norm cannot significantly affect the taxpayers' private norm on their tax obligations. It means that there is no significant effect between subjective norm on the intention to implement compliance because subjective norm, such as peers, have the effect to predict taxpayers' behavior. Friends colleagues do not play a role to encourage other peers to be professional and in realizing tax obligations that are in accordance with the prevailing provisions and regulations.

The second dimension that will be tested as a discussion of the research results in social norm variables is the descriptive norm in which the dimension is intended to help the individual determine the success of compliance and avoidance. It is because descriptive norm provides valuable information to individuals to guide behavior. From the dimensions, several indicators are built that include the total of taxpayers who avoid taxes and taxable income.

From the test results, a statement can be taken that the norm descriptive in social norm cannot mainly affect social norm in fulfilling their tax obligations. This result is also affected by individuals feeling that other taxpayers have a low intention to comply with taxes, then they have a lower moral, and will be more likely to avoid taxes. In the findings of this study, it is found that one of the things that become factors that make social norm does not affect the 
private norm on the object of research is that there is no norm descriptive generally in the research object.

The next dimension examined in the social norm variable is the injunctive norm in which the substance of this dimension aims to measure individuals looking for social consent to obey the norms. From this dimension, several indicators are built which include testing to comply with tax and business rules to avoid taxes. Besides, from the test results, a statement can be made that the norm in the social norm cannot necessarily affect the taxpayers' private norm in fulfilling their tax obligations. This result is also affected by the injunctive norm indicating the level where an individual feel that the public believes it is important to comply with the tax laws. The findings of this study reveal that one of the things becoming factors that cause social norm not affect compliance to the object of research is the reality that there is no general injunctive norm on the object of research.

Finally, it can be taken conclusions and explanations of the results of research about why the findings of research results show there is no effect between social norm and taxpayers' compliance on the object of research. From the research problems described above, the weakness of subjective norm, descriptive norm, and injunctive norm are the factors that cause social norm not have any effects on the taxpayers' personal norm on the object of research.

There is no Effect between Private Norm and Taxpayers' Compliance. The results of the above analysis test show that: the analysis does not support the hypothesis of $\mathrm{H} 4$. It reveals that the private norm needed by the taxpayers to achieve an overall high compliance do not have clear purpose and the spirit of objectivity achievement. It does not encourage and underpin a taxpayer in measuring the level of compliance. This finding is different from previous research conducted by Bobek et al. (2007) which examines 254 students and employees in Australia, Singapore and the United States. The results show that private norm is stronger than social norm. Thus, it can be concluded that there is a positive relationship between private norm and tax compliance.

A deeper discussion to see the root of the problem in this finding can be seen in the indicator of the tax personal norm variable. It should be noted that this study measures private norm by employing indicators of Jimenez and lyer (2016) in which the personal norm in this study is a tax compliance behavior that has significant moral and behavioral standards on all behaviors. There are several indicators such as testing moral mistakes, tax errors, and tax evasion of the study respondents. The results clearly portray that the indicators do not have an effect on compliance on the object of research.

The results of the test completely explicate that the indicators in the personal norm do not significantly affect taxpayers' compliance with tax obligations. It brings a meaning that there is no significant effect between the indicators of moral error, tax error, and tax avoidance to implement compliance because the norms personally are developed through the internalization of social norm in individual groups. It is because private norm reflects individuals themselves, then private norm has a significant effect over all behaviors including tax compliance behavior. All in all, it can be drawn conclusions and explanations of the results of research answering why the findings of research results reveal there is no effect between private norm and taxpayers' compliance on the research object. From the research problems formulation shown above, then the strength of moral error, the strength of tax error, and the strength of tax avoidance become the factors that cause social norm not have any effects on taxpayers' compliance on the research object.

There is an Effect between Private Norm and Government Trust. From the results of the analysis test above, it is found that the analysis results support H5 hypothesis. It completely reveals that private norm is frequently respected for government trust. Government trust is based on tax law; therefore, taxpayers compare the contribution of the tax system to the contribution of others. The findings of this study are in line with the findings of Jimenez and lyer (2016) stating that the variable of private norm affects private norm.

There is no Effect between Government Trust and Justice Perception. The results of the above analysis test show that: the analysis does not support the hypothesis of H6. It demonstrates that trust theory as heuristic provides insight into the effects of trust and help 
explain to individual regarding to support for government action. Thus, taxpayers with government relations, including their trust in government, are an important consideration when examining voluntary tax compliance. Trust in government has a significant effect on tax compliance. Consequently, the negative effect of government distrust can provide the means by which taxpayers rationalize tax avoidance.

The test results provide a statement that indicators in government trust do not significantly affect the perception of tax justice. It means that there is no effect between indicators in maintaining government trust, satisfactory quality, and tax benefits to implement tax justice

Eventually, it can make conclusions and explanations of the research results regarding to why the findings of research results show there is no effect between government trust and tax justice on the object of research. From the research problems explained above, the weakness of government trust, satisfactory quality, and tax benefits are the factors that cause the trust of the government does not have effect on taxpayer justice on the research object.

There is an Effect between Justice Perception and Taxpayers' Compliance. Based on the results of the above analysis test, it is found that the results of the analysis support the hypothesis of $\mathrm{H} 7$. It shows that the perception of justice can be especially important in tax compliance. Tax compliance supports the idea that perception of justice affects tax compliance. It is intended that the perception of justice is one of the three most important determinants of compliance; therefore. if the taxpayers accept that the tax system does not have a justice, they will be able to rationalize the avoidance. Overall, these results suggest that positive perception of justice is related to compliance. The findings of this study are in accordance with the findings of Jimenez and lyer (2016) which suggest that justice perception variable affects compliance.

Managerial Implications. The first managerial implication is that private norm has a positive effect on government trust. Trusting each other basically will build cooperation, which then can reduce the cost of transactions between people and then save the use of resources. Even as a result of mutual trust, many efforts are not needed to monitor or to supervise others to behave as expected. Trust will build a sense of responsibility and a sense of respect that will then lead to trust towards those who give the trust. Building trust takes a very long time, but it is often easily destroyed and when a society experiences mutual trust, building cooperation and arrangement will be difficult to achieve. The programs realized to encourage private norm to enhance government trust are: Improving the effectiveness of counseling and public relations by: Launching an integrated communication strategy. The background of this activity is as follows: (i) the community, especially the taxpayers, has different perceptions of the DGT; (ii) compliance with the fulfillment of tax obligations by taxpayers is still relatively low. Integrated communication strategy is one of the initiatives that aims to improve taxpayer compliance with the fulfillment of tax obligations through the implementation of education to taxpayers and the publication of tax law enforcement through the mass media, and to increase confidence to the DGT in the eyes of the community through the refinement of communication methods and the latest issues management proactively.

The programs undertaken to encourage justice in order to improve compliance are: compilation of compliance management model of Compliance Risk Management. Directorate General of Taxation (DGT) requires an integral and a comprehensive strategy built with a risk approach and is able to improve the quality of strategic decision making. To build such a strategy, a common commitment of all stakeholders, a reliable DSS, and policies and units that support the implementation of the strategy are needed. Thus, as a tax institution in a global environment, the DGT should apply Compliance Risk Management (CRM) which has also been applied to taxation units in some countries and is considered successful enough in formulating compliance risk management of taxpayers that give impact on the success of the state taxation unit in achieving its strategic goals. CRM is a systematic process in which the DGT makes choices on instruments that can be used to improve taxpayer compliance and prevent non-compliance effectively, based on the knowledge of all taxpayers' behavior and 
available DGT capacity. The purpose of this activity is to enable the DGT to achieve its strategic objectives by facilitating management to make better decisions. Strategic activities undertaken to support this activity are as follows: (i) creating awareness and commitment to all DGT stakeholders; (ii) designing risk engine as decision support an integrated and comprehensive system to manage the risk of non-taxpayer; and (iii) drafting policy concepts (business rules and processes) to support CRM implementation.

\section{CONCLUSION AND SUGGESTION}

From the results of the analysis tests, it is found that the analysis results do not support the hypothesis of $\mathrm{H} 1$. This finding reveals that the results of the study indicate that the subjective norm dimension does not have an effect on adherence to the object of study. From the test results, it can be made a statement that subjective norm in social norm cannot necessarily affect taxpayers' compliance with tax obligations. It means that there is no significant affect between subjective norms on the intention to implement compliance because subjective norm, such as colleagues, does not have the effect to predict taxpayers' behavior. Friends colleagues do not play a role to encourage peers to be professional and the realization of tax obligations encouraging each other should be in accordance with the prevailing provisions and regulations.

The second finding indicates that the results of the analysis do not necessarily support $\mathrm{H} 2$. It indicates that the indicator in the awareness of the taxpayers does not significantly affect taxpayers' compliance with their tax obligations. It means that there is no significant effect between the contribution of the people for development, the governments' duties running smoothly, and sustainable development to implement compliance because of taxpayers' awareness, human consciousness in understanding reality, and how to react or respond to reality.

The next analysis finding does not support the hypothesis of $\mathrm{H} 3$. It shows that social norm is often perceived by individual groups and become part of the individuals' private norm. The injunctive norm can function as an indicator of private norm because it refers to the perception of the trust of the private norm.

On the other hand, the results of analysis also do not necessarily support the hypothesis of $\mathrm{H} 4$ since the indicators in the private norm does not necessarily affect taxpayers' compliance with their tax obligations. It means that there is no significant effect between the indicators of moral error, the amount tax error, and the tax avoidance to implement compliance due to private norm developed through the internalization of social norm in individual groups. It is because private norm reflects individuals themselves; then private norm has a significant effect over all behaviors including tax compliance behavior.

Further analysis results also support the hypothesis of $\mathrm{H} 5$ which states that private norm is often understood for government trust. Government trust is based on tax law; hence, taxpayers compare the contribution of the tax system to the contribution of others.

Moreover, in this study, there is also an analysis result that supports hypothesis of $\mathrm{H} 6$ stating indicator in government trust does not necessarily affect the perception of tax justice. It means that there is a significant effect between the indicators of maintaining government trust, satisfactory quality, and tax benefits to uphold tax justice.

Eventually, the results of further analysis also support the hypothesis of $\mathrm{H} 7$ which states that the perception of justice can be essential especially in tax compliance. Tax compliance supports the idea that perception of justice affects tax compliance. It is intended that the perception of justice is one of the three most important determinants of compliance; hence if the taxpayers accept that the tax system does not have a justice, they will be able to rationalize the avoidance.

The present research can provide optimal benefits for further research objects and it can also be a comparative material in other studies. However, because this study has limitations, the object of research can be made further with the development by using a more homogeneous sample of its characteristics, for example by using a sample of taxpayers of 
individuals who have a certain business circulation with the type of business which is limited to a particular field.

\section{REFERENCES}

1. Alm, J. (1991). A perspective on the experimental analysis of taxpayer reporting. The Accounting Review, 66(3), 577-593.

2. Alm, J., Sanchez, I., and De Juan, A. (1995). Economic and noneconomic factors in tax compliance. Kyklos, 48(1), 1-18.

3. Alm, J., McClelland, G. H., and Schulze, W. D. (1999). Changing the social norm of tax compliance by voting. Kyklos, 52(2), 141-171.

4. Bobek, D. D., and Hatfield, R. C. (2003). An investigation of the theory of planned behavior and the role of moral obligation in tax compliance. Behavioral Research in Accounting, 15(1), 13-38.

5. Bobek, D. D., Roberts, R. W., and Sweeney, J. T. (2007). The social norms of tax compliance: Evidence from Australia, Singapore, and the United States. Journal of Business Ethics, 74(1), 49-64.

6. Bobek, D. D., Hageman, A. M., and Kelliher, C. F. (2013). Analyzing the role of social norms in tax compliance behavior. Journal of Business Ethics, 115(3), 451-468.

7. Cohen-Charash, Y., and Spector, P. E. (2001). The role of justice in organizations: A meta-analysis. Organizational behavior and human decision processes, 86(2), 278-321.

8. Cialdini, R. B., Kallgren, C. A., and Reno, R. R. (1991). A focus theory of normative conduct: A theoretical refinement and reevaluation of the role of norms in human behavior. Advances in experimental social psychology, 24, 201-234.

9. Cialdini, R. B., and Trost, M. R. (1998). Social influence: Social norms, conformity and compliance.

10. Cowell, F. A. (1990). Cheating the government: The economics of evasion. MIT Press Books, 1.

11. Cummings, R. G., Martinez-Vazquez, J., McKee, M., and Torgler, B. (2009). Tax morale affects tax compliance: Evidence from surveys and an artefactual field experiment. Journal of Economic Behavior and Organization, 70(3), 447-457.

12. Davis, J. S., Hecht, G., and Perkins, J. D. (2003). Social behaviors, enforcement, and tax compliance dynamics. The Accounting Review, 78(1), 39-69.

13. DeConinck, J. B. (2010). The effect of organizational justice, perceived organizational support, and perceived supervisor support on marketing employees' level of trust. Journal of Business Research, 63(12), 1349-1355.

14. Deutsch, M., and Gerard, H. B. (1955). A study of normative and informational social influences upon individual judgment. The journal of abnormal and social psychology, 51(3), 629.

15. Hubbell, A. P., and Chory-Assad, R. M. (2005). Motivating factors: Perceptions of justice and their relationship with managerial and organizational trust. Communication Studies, 56(1), 47-70.

16. Jimenez, P., and lyer, G. S. (2016). Tax compliance in a social setting: The influence of social norms, trust in government, and perceived fairness on taxpayer compliance. Advances in Accounting, 34, 17-26.

17. Klein, K. A., and Boster, F. J. (2006, June).Subjective, descriptive, and injunctive norms: Three separate constructs. Paper presented at theannual conference of the International Communication Association,Dresden, Germany

18. Leonardo, G. (2011). Politics and Tax Morale. The Role of Trust, Values, and Beliefs. Shaping Individual Attitudes Towards Tax ComplianceTesis de Doctorado. Georgia, Georgia State University.

19. Lerche, D. (1980). Efficiency of taxation in Indonesia. Bulletin of Indonesian Economic Studies, 16(1), 34-51.

20. Nail, P., McDonald, G. and Levy, D.(2000). Proposal of a four-dimensional model of social response. Psychological Bulletin 126, 454-470. 
21. Palil, M. R., Akir, M. R., and Ahmad, W. F. (2013). The perception of tax payers on tax knowledge and tax education with level of tax compliance: a study the influences of religiosity. ASEAN Journal of Economics, Management and Accounting, 1(1), 118-129.

22. Porcano, T., and C. Price. (1993). "The effects of social stigmatization on tax evasion." Advances in Taxation 5, 197-217.

23. Richardson, G. (2008). The relationship between culture and tax evasion across countries: Additional evidence and extensions. Journal of International Accounting, Auditing and Taxation, 17(2), 67-78.

24. Sanders, D. L., Reckers, P. M., and lyer, G. S. (2008). Influence of accountability and penalty awareness on tax compliance. Journal of the American Taxation Association, 30(2), 1-20.

25. Torgler, B. (2003). Tax morale in transition countries. Post-communist economies, 15(3), 357-381.

26. Torgler, B. (2007). Tax compliance and tax morale: A theoretical and empirical analysis. Edward Elgar Publishing.

27. Torgler, B., Demir, I. C., Macintyre, A., and Schaffner, M. (2008). Causes and consequences of tax morale: An empirical investigation. Economic Analysis and Policy, 38(2), 313-339.

28. Wenzel, M. (2002). The impact of outcome orientation and justice concerns on tax compliance: the role of taxpayers' identity. Journal of applied psychology, 87(4), 629.

29. Wenzel, M. (2004). The social side of sanctions: Personal and social norms as moderators of deterrence. Law and human behavior, 28(5), 547-567.

30. Wenzel, M. (2005). Motivation or rationalisation? Causal relations between ethics, norms and tax compliance. Journal of Economic Psychology, 26(4), 491-508. 